\title{
Invasion of the tropical earthworm Pontoscolex corethrurus (Rhinodrilidae, Oligochaeta) in temperate grasslands
}

\author{
Diana Ortiz-Gamino $^{1}{ }^{,}$Paulino Pérez-Rodríguez ${ }^{2}$, Angel I. Ortiz-Ceballos ${ }^{\text {Corresp. } 1}$ \\ 1 Instituto de Biotecnología y Ecología Aplicada, Universidad Veracruzana, Xalapa, Veracruz, Mexico \\ 2 Programa de Estadística, Colegio de Postgraduados, Texcoco, Estado de Mexico, Mexico \\ Corresponding Author: Angel I. Ortiz-Ceballos \\ Email address: angortiz@uv.mx
}

The tropical earthworm Pontoscolex corethrurus (Rhinodrilidae, Oligochaeta) presents a broad distribution (e.g., 56 countries from four continents). It is generally assumed that temperature appears to limit the success of tropical exotic species in temperate climates. However, the distribution range of this species could advance towards higher elevations (with lower temperatures) where no tropical species currently occur. The aim of this study was to evaluate the soil and climatic variables that could be closely associated with the distribution of $P$. corethrurus in four sites along an altitudinal gradient in central Veracruz, Mexico. We predicted that the distribution of $P$. corethrurus would be more related to climate variables than edaphic parameters. Five sampling points (in the grassland) were established at each of four sites along an altitudinal gradient: Laguna Verde (LV), La Concepción (LC), Naolinco (NA) and Acatlán (AC) at 11-55, 992-1025, 1550-1619 y 17721800 masl, respectively. The climate ranged from tropical to temperate along the altitudinal gradient. Ten earthworm species (5 Neotropical, 4 Palearctic and 1 Nearctic) were found along the gradient, belonging to three families (Rhinodrilidae, Megascolecide and Lumbricidae). Soil properties showed a significant association (positive for Ngrass, pH, permanent wilting point, organic matter and $\mathrm{P}$; and negative for Total $\mathrm{N}, \mathrm{K}$ and waterholding capacity) with the abundance of the earthworm community. Also there seems to be a relationship between climate and earthworm distribution along the altitudinal gradient. $P$. corethrurus was recorded at tropical (LV and LC) and temperate sites (NA) along the altitudinal gradient. Our results reveal that soil fertility determines the abundance of earthworms and site (climate) can act as a barrier to their migration. Further research is needed to determine the genetic structure and lineages of $P$. corethrurus along altitudinal gradients. 
1

2

3

4

5

6

7

8

9 Instituto de Biotecnología y Ecología Aplicada (INBIOTECA), Universidad Veracruzana,

\section{Soil and climate determine earthworm distribution along an altitudinal gradient:} Pontoscolex corethrurus inhabits temperate grasslands

\author{
Diana Ortíz-Gamino ${ }^{1}$, Paulino Pérez-Rodríguez ${ }^{2}$, and Angel I. Ortíz-Ceballos ${ }^{1 *}$
}

Av. de las Culturas Veracruzanas No. 10, Col. Emiliano Zapata, 91090 Xalapa, Veracruz, México.

${ }^{2}$ Programa de Estadística, Campus Montecillo, Colegio de Postgraduados, 56230, Montecillo, Estado de México, México.
16

*Corresponding Author: Instituto de Biotecnología y Ecología Aplicada (INBIOTECA), Universidad Veracruzana, Av. de las Culturas Veracruzanas No. 10, Col. Emiliano Zapata, 91090 Xalapa, Veracruz, México. angortiz@uv.mx 
22 Abstract

23

24

The tropical earthworm Pontoscolex corethrurus (Rhinodrilidae, Oligochaeta) presents a broad distribution (e.g., 56 countries from four continents). It is generally assumed that temperature appears to limit the success of tropical exotic species in temperate climates. However, the distribution range of this species could advance towards higher elevations (with lower temperatures) where no tropical species currently occur. The aim of this study was to evaluate the soil and climatic variables that could be closely associated with the distribution of $P$. corethrurus in four sites along an altitudinal gradient in central Veracruz, Mexico. We predicted that the distribution of $P$. corethrurus would be more related to climate variables than edaphic parameters. Five sampling points (in the grassland) were established at each of four sites along an altitudinal gradient: Laguna Verde (LV), La Concepción (LC), Naolinco (NA) and Acatlán (AC) at 11-55, 992-1025, 1550-1619 y 1772-1800 masl, respectively. The climate ranged from tropical to temperate along the altitudinal gradient. Ten earthworm species (5 Neotropical, 4 Palearctic and 1 Nearctic) were found along the gradient, belonging to three families (Rhinodrilidae, Megascolecide and Lumbricidae). Soil properties showed a significant association (positive for $\mathrm{N}_{\text {grass, }} \mathrm{pH}$, permanent wilting point, organic matter and $\mathrm{P}$; and negative for Total N, K and water-holding capacity) with the abundance of the earthworm community. Also there seems to be a relationship between climate and earthworm distribution along the altitudinal gradient. P. corethrurus was recorded at tropical (LV and LC) and temperate sites (NA) along the altitudinal gradient. Our results reveal that soil fertility determines the abundance of earthworms and site (climate) can act as a barrier to their migration. Further research is needed to determine the genetic structure and lineages of $P$. corethrurus along altitudinal gradients. 


\section{Introduction}

48

49

50

51

52

53

54

55

56

57

58

59

60

61

62

63

64

65

66

67

Within soil biodiversity, earthworms are key components of the guild of ecosystem engineers (Jones et al. 1994). They provide a considerable level of ecosystem services, such as contributing to biogeochemical cycling and crop productivity (Turbé et al. 2010; Orgiazzi et al. 2016). Depending on their ecological classification (epigeic, endogeic or anecic), they can also modify the distribution and abundance of soil biodiversity, mainly by constructing structures and galleries within the soil profile and by producing casts and mucus (Turbé et al. 2010; Orgiazzi et al. 2016).

Most earthworm communities display an aggregated spatial distribution in response to soil environmental heterogeneity at a small scale (Geissen et al. 2009; Huerta et al. 2012; Jiménez et al. 2012). This is relevant because of the limited capabilities of earthworms for horizontal displacement, between 4 and 10 m per year (Brown et al. 2006; King et al. 2008), and may thus have had the opportunity to diversify allopatrically over relatively short distances (Bickford 2005; King et al. 2008). Nevertheless, climate has a substantial influence on earthworms (physiology, development or activity) that is reflected in the seasonal dynamics of their life history (Curry 2004; Turbé et al. 2010; Orgiazzi et al. 2016).

At the global level, apart from studies in North America where non-native earthworms are causing changes in soil biota and plant communities, little recognition has been given to invasions of soil organisms (Gates 1954; Bohlen et al. 2004; Fahey et al. 2013). Among the 3700 earthworm species described, approximately 3\% (100-120) have been identified as invasive; for example, the ubiquitous Pontoscolex corethrurus (Müller 1857), several temperate species from 
genera Amynthas and at least 10 species of Lumbricid (Brown et al. 2006; Beddard 1912; Hendrix et al. 2008; Dupont et al. 2012). These earthworms have reached a broad distribution in many tropical and temperate agroecosystems and natural ecosystems. However, this has been facilitated by fishing bait, horticulture, waste management industries, road networks and vehicle transport which have contributed to surmount important biogeographic barriers (Eisen 1900; Beddard 1912; Gates 1954; Hendrix et al. 2008).

P. corethrurus "Brush-tail" is native to the Guiana Shield area of the Amazon (Müller 1857; Brown et al. 2006; Dupont et al. 2012). Due to a high level of genetic diversity in populations (Dupont et al. 2012; Cunha et al. 2014), its adaptive strategies include a high tolerance to soil conditions and climatic variables (precipitation) (Lavelle et al. 1987; González et al. 2006; González et al. 2007). For this reason, P. corethrurus is established throughout the tropical regions of over 56 countries (González et al. 2006). Given the wide distribution range of P. corethrurus, this species can be used as a model organism to investigate and compare the effects of native and introduced species on ecosystem processes. $P$. corethrurus generally plays a beneficial role in soils; that is, it has the potential to improve plant growth and productivity (Senapati et al. 1999; Van Groenigen et al. 2014; Cunha et al. 2016), and is used as a key indicator in toxicological research (Zavala et al. 2013; García-Pérez et al. 2014). There are very few cases of negative or null effects of $P$. corethrurus (Brown et al. 2006); but soil compaction may be induced under particular situations (Gates 1954; Chauvel et al. 1999; Barros et al. 2004). In Mexico, since the early twentieth century, $P$. corethrurus has been the endogeic earthworm most commonly found in human-altered tropical ecosystems (Eisen 1900; Lavelle et al. 1987; Brown et al. 2004; Fragoso and Rojas 2014). However, the edge of the earthworm's distribution range could advance towards higher elevations where few or no tropical species 
91 currently occur (Eisen 1900; Beddard 1912; Hendrix et al. 2008). The aim of this study was to

92 evaluate the soil and climatic variables that could be closely associated with the distribution of $P$.

93 corethrurus. We predicted that the distribution of $P$. corethrurus would be more related to

94 climatic variables than edaphic parameters. We tested this hypothesis through a study of the

95 earthworm community along an altitudinal gradient in central Veracruz, Mexico. In addition, we

96 compared the occurrence of four possible situations in the altitudinal gradient (Marichal et al.

97 2010): a) presence of $P$. corethrurus only, b) coexistence of $P$. corethrurus and other species

98 (native and invasive), c) absence of $P$. corethrurus but presence of other species (native and

99 exotic), and d) absence of earthworms.

101 Methods

102 Study area

103 An altitudinal transect, ranging from 11 to 1800 masl, was established in the central 104 region of the State of Veracruz, Mexico. Five sampling points were established at each of four 105 sites along this altitudinal gradient (Fig. 1): Laguna Verde (LV), La Concepción (LC), Naolinco 106 (NA) and Acatlán (AC) at 11-55, 992-1025, 1550-1619 and 1772-1800 masl, respectively. (http://www.conagua.gob.mx) was compiled for each site along the altitudinal transect. The monthly and annual 30-year averages were obtained for the following climate variables: average

110 temperature (AT), average maximum temperature (AMT), average minimum temperature 111 (AmT), total annual precipitation (TAP) and total evaporation (TE). With these data, climate 112 types along the altitudinal gradient were determined using the Clima2 software 
113 (http://www.pablo-leautaud.com/home/proyectos/python/clima) and classified into one climate

114 type according to the Köppen-Geiger system (Kottek et al. 2006; Peel et al. 2007).

115

116 Earthworm sampling

117 For determining the distribution of earthworms, we choose the grasslands because they are a 118 suitable habitat that fosters the growth of earthworms, and can be found along the altitudinal 119 gradient. These grasslands are used as pasture for both an extensive (LV and LC) and semi120 intensive cattle farming (NA and AC) under a rotational use of pasture (30-45 day grazing-rest 121 cycle) and without the application of mineral fertilization (Lavelle et al. 1981; Brown et al. 122 2004). The grasses species that grow in these grassland are: a) native: sour paspalum Paspalum 123 conjugatum P.J. Bergius (80\% LV, 60\% LC, 40\% NA, and 40\% AC), b) introduced: 124 bermudagrass or stargrass Cynodon nlemfuensis Vanderyst (20\% LV, 40\% LC, and 40\% NA) 125 and kikuyu Pennisetum clandestinum Hochst. Ex Chiov. (20\% NA, and 60\% AC). In the 126 extensive production system (Dual-purpose cattle systems: milk and meat), cattle (Bos indicus $\mathrm{x}$ 127 Bos Taurus cows: Zebu x Swiss or Holstein) was fed only on forage produced in grassland, 128 ocassionaly suplemented with mineral salts. By contrast, under the semi-intensive system (milk), 129 besides feeding on grassland forage, milk cows (Holstein) are given a dietary supplement made 130 of carbohydrates (corn and barley stubble), protein (cane molasses, urea, dehydrated alfalfa and 131 others) and mineral salts.

132 The quantitative sampling of earthworms was conducted along the altitudinal gradient 133 (ISO 2011). One monolith (25 x $25 \times 30 \mathrm{~cm}$ deep) according to Anderson and Ingram (1993) was 134 sampled at each of the five sampling points (in the grassland) established at least $200 \mathrm{~m}$ apart 135 (Marichal et al. 2010), located at each of the four sites on the altitudinal transect, for a total of 20 
136 monoliths along the altitudinal transect. Each monolith was separated into four strata: above-

137 ground plant biomass, 0-10, 10-20 and 20-30 cm. Earthworms were then manually removed from

138 each layer and preserved in $70 \%$ ethanol. In the laboratory, all specimens were fixed in $4 \%$

139 formaldehyde and then identified (to species or morphospecies), quantified and weighed. The

140 sampling was conducted at the end of the rainy season (August-October 2011). Abundance and

141 biomass data of the earthworms were converted into densities per square metre (ind. $\cdot \mathrm{m}^{-2}$ and $\mathrm{g}$ $142 \cdot \mathrm{m}^{-2}$, respectively) for each site (ISO 2011).

144 Soil and foliage sampling

145 Prior to removing the earthworms, the biomass of grass was harvested from each monolith. In 146 the laboratory, this plant material was dried $\left(60^{\circ} \mathrm{C}\right.$ for $\left.72 \mathrm{~h}\right)$ and weighed, and its total nitrogen 147 content $\left(\mathrm{N}_{\text {grass }}\right)$ was determined using the Kjeldahl methods described in the Mexican Official 148 Standard NOM-02-RECNAT-2000 (SEMARNAT 2002).

149 Following the removal of earthworms, a 1-kg soil sample was taken from each stratum of 150 each monolith. Soil samples were air-dried to constant weight and sieved (5 $\mathrm{mm})$ to determine 151 the texture (clay, silt and sand), water-holding capacity, permanent wilting point, $\mathrm{pH}$, organic 152 matter, Total C, Total N, P and K, using the methods described in the Mexican Official Standard 153 NOM-02-RECNAT-2000 (SEMARNAT 2002).

155 Statistical analysis

156 A one-way ANOVA was used to test for significant differences $(P<0.05)$ in soil properties 157 between sites, using the Statistica software, ver. 7 (StatSoft, Tulsa, OK, USA). 
161 (figure not shown) of the scores for the first two principal components obtained from a PCA of Mixed Models to take into account the sampling design consisting in clustered samples and the response variable measured at two different scales, i.e., soil properties at the sample scale and climatic conditions at the site scale. The results showed that the variance component associated with the site effect was misleading. Apart from the linear models and before log-transforming the data, we also fitted generalized linear models with different families (e.g., Poisson, Negative Binomial); however, some convergence issues arose when fitting the models. Consequently, only the results for the fitted Linear Model are reported here.

\section{Results}

\section{Site climate}

175 The climate along the altitudinal gradient, from the lowest to the highest elevation sites, 176 according to Kottek et al. (2006) and Peel et al. (2007) ranged from warm to humid tropical 177 (Aw) to temperate $(\mathrm{Cfb})$ (Table 1). There was a difference of approximately $11{ }^{\circ} \mathrm{C}$ in the 178 average, minimum and maximum temperatures between the lowest (LV, 11-55 masl) and the 179 highest elevation sites (AC, 1772-1800 masl) along the gradient. Rainfall was higher in site LC 
$180(1676.8 \mathrm{~mm})$ than in site LV (1143.0 mm), whereas sites NA and AC (1550-1619 and 1772-1800

181 masl) had intermediate values of $1461 \mathrm{~mm}$ (Table 1).

182

183

184

185

186

187

188

189

190

191

192

193

194

195

196

197

198

199

200

201

Soil properties and foliage

The physical and chemical variables of soil and nutritional quality of pasture along the altitudinal gradient displayed significant variations between tropical (LV and LC) and temperate (NA and AC) sites (Table 2). According to and the official Mexican standard soil fertility (SEMARNAT 2002), soils from tropical sites had a heavy texture (clay loam; Regosols, Phaeozems and Vertisols; Krasilnikov et al. 2013); were mildly acidic; and displayed intermediate values for water-holding capacity and permanent wilting point; were very rich in organic matter, total $\mathrm{N}$ and $\mathrm{P}$; and were extremely poor in $\mathrm{K}$. In contrast, soils from temperate sites had a light texture (loam; Andosols); greater water-holding capacity and permanent wilting point; were slightly acidic; and were very rich in organic matter, total $\mathrm{N}$ and $\mathrm{P}$; and were extremely poor in $\mathrm{K}$. Quality grass $\left(\mathrm{N}_{\text {grass }}\right)$ in the temperate sites (NA and AC) was higher compared to tropical sites (LC an LC).

\section{Earthworm communities}

Ten earthworm species (Annelida: Oligochaeta: Crassiclitellata) were found in the whole sampling (Table 3). Seven of these are well-known, ubiquitous species, some of which are considered invasive, belonging to three different families (Rhinodrilidae, Megascolecidae and Lumbricidae). The remainder of the earthworms were native morphospecies (differentiated from others only by morphological features). The highest diversity was found at site AC, with five 
202 species. The total abundance of the earthworm community ranged from 0 to $864 \mathrm{ind} \cdot \mathrm{m}^{-2}$ (Fig. 2),

203 with an average of 332 ind. $\cdot \mathrm{m}^{-2}$.

204 The LM analysis showed that the total abundance of the earthworm was significantly 205 influenced by water-holding capacity $(P=0.026)$, permanent wilting point $(P=0.019), \mathrm{pH}(P=$ $2060.045)$, organic matter $(P=0.029)$, Total N $(P=0.015), \mathrm{P}(P=0.031), \mathrm{K}(P=0.016)$ and $\mathrm{N}_{\text {grass }}$ $207(P=0.009)$, while the climatic factors (sites) had no such effect $(\mathrm{F}=5.57 ; P=0.0652)$. That is, 208 positive coefficients were associated with an increase in the number of earthworms, and negative 209 coefficients were associated with a decrease in the number of earthworms (Table 4).

\section{Pontoscolex corethrurus}

212

Populations of $P$. corethrurus were found in 10 of the 20 samples from the gradient (Fig.

214 (situated at 1772-1800 masl).

On average, the abundance of $P$. corethrurus accounted for $73 \%$ of the total earthworm sites LV, LC and NA at 92, 79 and 47\%, respectively (Fig. 2b). In the sites where the species occurred, its average density was 273.5 ind. $\cdot \mathrm{m}^{-2}$, ranging from 16 to 704 ind. $\cdot \mathrm{m}^{-2}$ (Fig. $2 \mathrm{c}$ ). alone in 3 of the 5 monoliths of site LC, while only native species were found alone in site LV.

\section{Discussion}


224 Earthworm communities are determined by hierarchical organized factors: temperature operates

225 at the highest hierarchical level, followed by soil nutrient and seasonality factors (Gerard 1967;

226 Fragoso and Lavelle 1992; Briones et al. 2009; Eisenhauer et al. 2014). Compared to other types

227 of terrestrial ecosystems, grasslands (which are the best carbon storage systems) are structurally

228 simple and appear to be relatively homogeneous in terms of richness and functional complexity,

229 particularly belowground (Stockdill 1966; Stanton 1988; Brown et al. 2004). Here, we found that

230 along an altitudinal gradient, site (climate) can act as a barrier to distribution of peregrine

231 earthworms and their abundance was determined significantly by soil fertility and grass quality.

232

233 Earthworm community

234 Along the altitudinal gradient studied here, 10 species (seven exotic and three native 235 morphospecies) were recorded in the grassland. The exotic species are among the 51 exotic 236 species recorded in Mexico, and the three morphospecies are among the 40 native species that 237 are already known but still undescribed (Fragoso and Rojas 2014). Of the ten species that we 238 found, five are Neotropical (P. corethrurus Onychochaeta windelei and three morphspecies), 239 three are Western Palearctic (Lumbricus rubellus, Aporrectodea trapezoides and Octolasion 240 tyrtaeum), one is Nearctic (Bimastos parvus) and one more is Eastern Palearctic (Amynthas 241 gracilis). The earthworm diversity was similar (five species) between the tropical (LV and LC) 242 and temperate sites (NA and AC), similar to the diversity (4-14 species) that has been observed 243 in tropical and temperate forests (Fragoso and Lavelle 1992).

244 The current state of knowledge allows little generalization about the distribution patterns 245 of invasive earthworms, as is the case of P. corethrurus (Hendrix et al. 2008). However, Beddard 246 (1912) suggested that: a) temperate species tend to invade temperate regions and montane areas 
247 of the tropical regions, and b) tropical earthworms only tend to invade tropical regions; that is,

248 low temperatures limit their colonization of temperate areas. Our results show a trend for the

249 influence of climate (site) on the distribution of earthworm species throughout the altitudinal

250 gradient: the Palearctic and Nearctic species where only found in the temperate sites (NA and

251 AC) and the Neotropical species only in the tropical sites (LV and LC). However, P. corethrurus

252 was found in one temperate (NA), and A. gracilis in one tropical (LC) site, respectively. Some

253 characteristics of native species (morph 1 and 3) and their soil habitats (e.g., high content of

254 expending clay) might be resistant to introduction of $P$. corethrurus in the site LV, that is,

255 because their presence around this site was registered 35 years ago (Lavelle et al. 1981). Also

256 just as recorded by Juaréz and Fragoso (2014) and this study (site AC) P. corethrurus does not

257 coexist with $L$. rubellus and A. trapezoides. In contrast, P. corethrurus coexists with Palearctic

258 (A. gracilis and O. tyrtaeum) species as observed by Huerta et al. (2014) and Juaréz and Fragoso

259 (2014), respectively. Furthermore, P. corethrurus coexist with Neotropical (morph 2 and $O$.

260 windelei) species.

261

Grasslands have a positive effect on earthworm diversity and abundance, which is in line

with known habitat preferences (Stockdill 1966; Stanton 1988; Brown et al. 2004; Rutgers et al.

2016). In this study the diversity and density of earthworms along the altitudinal gradient

264 (ranging from 1-10 and 80-864 ind. $\mathrm{m}^{-2}$, respectively) fall within the range reported (1-35 and 6-

850 ind. $\mathrm{m}^{-2}$, respectively) for grasslands, croplands and forests of different tropical and

temperate regions of Mexico (Fragoso and Lavelle 1992; Ordaz et al. 1996; Brown et al. 2004;

267 Huerta et al. 2007; Geissen et al. 2009; Huerta et al. 2012; Uribe et al. 2012; Lavelle et al. 1987;

268 Fragoso and Coria-Martínez 2009; Juárez and Fragoso 2014), Puerto Rico (González et al.

269 2007), Colombia (Feijoo et al. 2010; Marichal et al. 2010; Gutiérrez-Sarmiento and Cardona 
270 2014), Brasil (Marichal et al. 2010), USA (Fahey et al. 2013; Crumsey et al. 2014; Eisenhauer et

271 al. 2014), Canada (Eisenhauer et al. 2007) and Europe (Rutgers et al. 2016).

272 In grasslands, the net primary productivity and the secondary productivity take place in

273 the soil: the former as rhizosphere (root and exudates), and the latter as soil biota (Stockdill

274 1966; Stanton 1988; Trujillo et al. 2005). El higher organic matter, N and P content in soils

275 across the altitudinal gradient derives from (Beetle 1974; Trevaskis et al. 2004; Wright et al.

276 2004; Trujillo et al. 2005; Mislevy and Martin 2006; Jones et al. 2016): a) the higher productivity

277 and nutrient quality of introduced grasslands (C. nlemfuensis and P. clandestinum), b)

278 carbohydrate and protein supplementation (NA and AC), and c) low cattle density (one animal

279 per hectare). This allows to incorporate a higher amount of leaf and root litter, dung and urine

280 into soil; that is, well-managed grasslands have the potential to sequestrate large amounts of

281 carbon and nutrients ( $\mathrm{Lal}$ 2004; Wright et al. 2004; Jones et al. 2016). Also, our results, showed

282 that the total abundance of earthworms, irrespective of the species is explained by foliage quality

283 (nitrogen) in the pasture, and soil fertility; that is, we found that $\mathrm{N}_{\text {grass, }}$, organic matter, $\mathrm{pH}, \mathrm{P}$ and

284 permanent wilting point increase abundance, while total $\mathrm{N}, \mathrm{K}$ and water-holding capacity

285 apparently reduce it. This has also been documented in other field (Zou and González 1997;

286 Brown et al. 2004; González et al. 2007; Geissen 2009; Huerta and Van der Wal 2012; Huerta et

287 al. 2012; Jiménez et al. 2012; Uribe et al. 2012) and laboratory studies (Patrón et al. 1999;

288 Ganihar 2003; Marichal et al. 2012). Soil organic matter is an important 'building block' for soil

289 structure, to absorb water, to retain nutrients and for aeration (Turbé et al. 2010). Also,

290 earthworms have higher abundance in soils with $\mathrm{pH}$ from 5 to 7 (LV, LC, NA and AC) and P is

291 maximised when it is in this pH range (Lavelle et al. 1987; González et al. 2007; Marichal et al.

292 2010). Also, soil with high silt contents (LV, LC, NA and AC) is a favourable habitat for 
293 earthworms (Huerta et al. 2007; Geissen et al. 2009; Marichal et al. 2010; Huerta et al. 2012).

294 However, abundance of earthworms is directly affected by the reduction of soil organic matter

295 content and indirectly by the reduction in plant diversity and productivity (Brown et al. 2004;

296 Brown et al. 2006; Marichal et al. 2010).

297

298 P. corethrurus

299 Our results showed that the most common species, with the exception of AC, along an altitudinal 300 gradient was the endogeic $P$. corethrurus. Several field studies in different tropical regions of 301 Mexico (Lavelle et al. 1987; Ordaz et al. 1996; Brown et al. 2004; Huerta et al. 2007; Fragoso 302 and Coria-Martínez 2009; Geissen et al. 2009; Huerta et al. 2012; Uribe et al. 2012; Juárez and 303 Fragoso 2014) and other tropical countries (Zou 1993; Jiménez et al. 1999; Hallaire et al. 2000; 304 Barros et al. 2004; Zou and González 2004; González et al. 2007; Jiménez et al. 2009; Feijoo et 305 al. 2010; Fonte and Six 2010; Marichal et al. 2010) have documented that P. corethrurus 306 populations (from 0-804 ind. $\mathrm{m}^{-2}$ ) are only found in environments with an average annual 307 temperature of $24.1 \pm 3.9^{\circ} \mathrm{C}$ (range: 16 to $33^{\circ} \mathrm{C}$ ), similar to sites $\mathrm{LV}$ and LC that show average 308 earthworm densities of 140 and 329 ind. $\cdot \mathrm{m}^{-2}$, respectively. However, our findings reveal that the 309 site LV is characterized by the absence of $P$. corethrurus in soils with a higher clay content (4:5 monoliths) and its presence associated with higher sand content (1:5 monoliths); similar findings

311 were observed by Lavelle et al. (1981) y Fragoso et al. (2006) in LV: Palma Sola (clayey) and 312 La Mancha (sandy), respectively. Contrary to the remarks by Buch et al. (2011), our results 313 suggests that soils with a heavy texture (predominance of expandable clays) restrains the 314 survival, growth and movement (for instance, by its brush-tail) of $P$. corethrurus, since soil is 315 characterized by: a) humidity levels delimited between hydric stress (high temperature) and 
316 excess water (flooding), b) adhesivity when wet, and c) hardness when dry. Furthermore, our

317 results suggest that the native morphospecies recorded prevent the establishment of $P$.

318 corethrurus, similar to the findings reported by Lavelle et al. (1981) and Fragoso (2011) in

319 clayey soils in LV (Palma Sola), where only native species were found: Ramiellona sp. Nov24,

320 Lavellodrilus parvus, Larsonidrilus microscolecinus, Diplotrema sp. Nov9 y Diplocardia sp.

321 Nov4. Marichal et al. (2010) suggest that P. corethrurus and the native species respond to

322 different sets of conditions with variations that are independent between them. Thus, the

323 biological resistance of native communities has been postulated as a key element to understand

324 the presence of $P$. corethrurus in some habitats bot not in others (Ortiz-Ceballos et al. 2004,

325 Ortiz-Ceballos et al. 2007; Marichal et al. 2012).

326 In addition, Eisen (1900) states that $P$. corethrurus "possesses a great vertical range. I do

327 not think, however, that it occurs in localities subject to frost" We observed populations of $P$.

328 corethrurus (with an average of 133 ind. $\cdot \mathrm{m}^{-2}$ ) at 1550-1619 masl (site NA), where the average

329 annual temperature is $17{ }^{\circ} \mathrm{C}$. In San Jerónimo Tecoatl (Oaxaca, Mexico; Juárez and Fragoso

330 2014), Drakensberg (KwaZulu-Natal, South Africa; Plisko 2001; Janion-Scheepers et al. 2016),

331 Antsirabe region of Madagascar (Chapuis-Lardy et al. 2010; Villenave et al. 2010), Curitiba

332 (Paraná State, Brazil; Buch et al. 2011), Zipacón (Cundinamarca, Colombia; Gutiérrez-

333 Sarmiento and Cardona 2014), Chatham (New Jersey, USA; Nearctic region; Gates 1954) and

334 São Miguel island (the Azores Archipelago; Palearctic region; Cunha et al. 2014), P. corethrurus

335 has become established under similar temperatures (Kottek et al. 2006; Peel et al. 2007; Orgiazzi

336 et al. 2016). This suggests that the growth and reproduction of $P$. corethrurus may no longer be

337 limited by temperature, as indicated by Lavelle et al. (1987) with ranges of $20-30{ }^{\circ} \mathrm{C}$ and $23-27$

$338{ }^{\circ} \mathrm{C}$, respectively (Zund et al.1997; Barois et al. 1999; Patrón et al. 1999; Ganihar 2003; García 
339

340

341

342

343

344

345

346

347

348

349

350

351

352

353

354

355

356

357

358

359

360

361

and Fragoso 2003; Topoliantz and Ponge 2005; Lafont et al. 2007; Chapuis-Lardy et al. 2010; Hernández-Castellanos et al. 2010; Lardy et al. 2010; Villenave et al. 2010; Buch et al. 2011; Chaudhuri and Bhattacharjee 2011; Marichal et al. 2012; Duarte et al. 2014; Kok et al. 2014; Nath and Chaudhuri 2014). In these studies, authors have found much faster or slower life cycles, mainly depending on the temperature of incubation and where they were collected (Buch et al. 2011).

Rapid adaptations or mutations in known invasive species should be considered as likely mechanisms that could facilitate their spread into new habitats (Hendrix et al. 2008). Genetic studies have shown a high level of genetic diversity in populations of $P$. corethrurus and they are probably differentiated into cryptic species (Dupont et al. 2012; Cunha et al. 2013). Our findings suggest that $P$. corethrurus inhabiting temperate grasslands is a lineage different to sites LV and LC. The correct molecular identification of P. corethrurus is needed to comprehend their history of colonization and as a baseline for biology, ecology and ecotoxicology research on this species (King et al. 2008; Dupont et al. 2012; Cunha et al. 2013).

3

\section{Conclusions}

Our results showed that soil quality significantly determined the abundance of the earthworm community along an altitudinal gradient. In addition, climate was shown to be a barrier to distribution of peregrine earthworms as suggested by Beddard (1912). P. corethrurus inhabiting tropical and temperate grasslands probably have 2-3 different lineages or ecotypes. Further studies will be needed to elucidate the genetic diversity of $P$. corethrurus.

\section{References}


Anderson RV, Ingram JS. 1993. Tropical Biology and Fertility: A handbook of Methods. CAB International, Wallinford, UK.

Barois I, Lavelle P, Brossard M, Tondoh J, Martínez MR, Senapati BK, Angeles A, Fragoso C, Jiménez JJ, Decaens T, Lattaud C, Kanyonyo J, Blanchart E, Chapuis L, Brown GG, Moreno A. 1999. Ecology of earthworm species with large environmental tolerance and/or extended distributions. In: Lavelle P, Brussard L, Hendrix P (eds.), Earthworm management in tropical agroecosystems. CAB International, Wallingford, pp. 57-85.

Barros E, Grimaldi M, Sarrazin M, Chauvel A, Mitja D, Desjardins T, Lavelle P. 2004. Soil physical degradation and changes in macrofaunal communities in Central Amazon. Applied Soil Ecology 26:157-168.

Beddard FE. 1912. Earthworms and Their Allies. University Press. Cambridge, UK.

Beetle AA. 1974. Sour Paspalum-Tropical weed or forage?. Journal of Range Management 27:347-349.

Bickford D, Lohman DJ, Sodhi NS, Ng PKL, Meier R, Winker K, Ingram KK, Das I. 2005. Cryptic species as a window on diversity and conservation. Trends in Ecology and Evolution 22:149-155

\section{Bohlen PJ, Groffman PM, Fahey TJ, Fisk MC, Suárez E, Pelletier DM, Fahey RT.} 2004. Ecosystem consequences of exotic earthworm invasión of North temperate forest. Ecosystems 7:1-12.

Briones MJI, Ostle NJ, McNamara NP, Poskitt J. 2009. Funtional shifts of grassland soil communities in response to soil warming. Soil Biology \& Biochemistry 47:315-322. 
384

385

386

387

388

389

390

391

392

393

394

395

396

397

398

399

400

401

402

403

404

Brown GG, James SW, Pasini S, Nunes DH, Benito NP, Trigo MP, Sautter KD. 2006.

Exotic, peregrine, and invasive earthworms in Brazil: diversity, distribution, and effects on soils and plants. Caribb. J. Sci. 42:339-358.

Brown GG, Moreno A, Barois I, Fragoso C, Rojas P, Hernández B, Patrón JC. 2004. Soil macrofauna in SE Mexican pastures and the effect of conversion from native to introduced pastures. Agr. Ecosyst. Environ. 103:313-327.

Buch AC, Brown GG, Niva CC, Sautter KD, Lourençato LF. 2011. Life cycle of Pontoscolex corethrurus (Muller, 1857) in tropical artificial soil. Pedobiologia 54S:S19-S25.

Chapuis-Lardy L, Brauman A, Bernard L, Pablo AL, Toucet J, Mano MJ, Weber L, Brunet D, Razafimbelo T, Chotte JL, Blanchart E. 2010. Effect of the endogeic earthworm Pontoscolex corethrurus on the microbial structure and activity related to $\mathrm{CO}_{2}$ and $\mathrm{N}_{2} \mathrm{O}$ fluxes from a tropical soil (Madagascar). Applied Soil Ecology 45:201208.

Chaudhuri PS, Bhattacharjee SB. 2011. Reproductive biology of eight tropical earthworm species of rubber plantations in Tripura, India. Tropical Ecology 52:49-60.

Chauvel A, Grimaldi M, Barros E, Blanchart E, Sarrazin M, Lavelle P. 1999. An amazonian earthworm compact more than a bulldozer. Nature 398:32-33.

Cunha L, Brown G, Stanton DWG, Da Silva, Hansel FA, Jorge G. 2016. Soil animals and pedogenesis: the role of earthworms in anthropogenic soils. Soil Science 181:110125. 
405

406

407

408

409

410

411

412

413

414

415

416

417

418

419

420

421

422

423

424

425

426

427

Cunha L, Montiel R, Novo M, Orozco-terWengel P, Rodrigues A, Morgan AJ, Kille P. 2014. Living on a volcano's edge: genetic isolation of an extremophile terrestrial metazoan. Heredity 112:132-142.

Curry JP. 2004. Factors affecting the abundance of earthworms in soils. In: Earthworm Ecology. CRC Press, Boca Raton. pp. 91-113.

Duarte AP, Melo FV, Brown GG, Pauletti V. 2014. Earthworm (Pontoscolex corethrurus) survival and impacts on properties of soils from a lead mining site in Southern Brazil. Biol. Fertil. Soils 50:851-860.

\section{Dupont L, Decaëns T, Lapied E, Chassany V, Marichal R, Dubs F, Maillot M, Roy V.} 2012. Genetic signature of accidental transfer of the peregrine earthworm Pontoscolex corethrurus (Clitellata, Glossoscolecidae) in French Guiana. Eur. J. Soil Biol. 53:70-75.

Eisen G. 1900. Researches in the American Oligocheta, with special reference to those of the Pacific coast and adjacent islands. Proceedings of California Academy of Science 2:85276

Eisenhauer N, Partsch S, Parkinson D, Scheu S. 2007. Invasion of a deciduous forest by eaarthworms: changes in soil chemistry, microflora, microarthropods and vegetation. Soil Biology \& Biochemistry 39:1099-1110.

Eisenhauer N, Stefanski A, Fisichelli NA, Rice K., Rich, R, Reich PB. 2014. Warming shifts 'worming: effects of experimental warming on invasive earthworms in northern North America. Scientific Reports 4:6890.

Fahey TJ, Yavitt JB, Sherman RE, Maerz JC, Groffman PM, Fisk MC, Bohlen PJ. 2013. Earthworms, litter and soil carbon in a northern hardwood forest. Biogeochemistry 114:269-280 


\section{Feijoo MA, Zúñiga MC, Quintero H, Carvajal-Vanegas FC, Ortiz DP. 2010. Patrones}

de asociación entre variables del suelo y usos del terreno en la cuenca del río la Vieja, Colombia. Acta Zoológica Mexicana (n.s.) Número Especial 2:151-164.

Fonte SJ, Six J. 2010. Earthworms and litter management contributions to ecosystem services in a tropical agroforestry system. Ecol. Appl. 20:1061-1073.

Fragoso C, Rojas P. 2014. Biodiversidad de lombrices de tierra (Annelida: Oligochaeta: Crassiclitellata). Rev. Mex. Biodivers. Supl. 85:S197-S207.

Fragoso C. 2011. Lombrices de tierra (Annelida: Oligocheta). In: La biodiversidad en Veracruz: estudio de estado. Vol. II. Diversidad de especies: conocimiento actual. Comisión Nacional para el Conocimiento y Uso de la Biodiversidad (CONABIO), Gobierno del Estado de Veracruz, Universidad Veracruzana, Instituto de Ecología, A.C. México, pp. 259-268.

Fragoso C, Coria-Martínez ML, Camarena LM. 2009. An update of the earthworm fauna of LosTuxtlas Ver. and adjacent regions: Are native species in the risk of extinction? In: Barois I, Huising EJ, Okoth P, Trejo D, De los Santos M (eds.) Below-Ground Biodiversity in Sierra San Marta, Los Tuxtlas, Veracruz, México. pp. 219-228.

Fragoso C, Lavelle P. 1992. Earthworm communities of tropical rain forests. Soil Biology \& Biochemistry 24:1397-1408

Fragoso C, Ángeles JA, Cruz Y. 2006. Las lombrices de tierra. In: Moreno-Casasola P (ed.) Entornos veracruzanos: la costa de La Mancha. Instituto de Ecología, A.C. Xalapa, México, pp. 476-490.

Ganihar SR. 2003. Nutrient mineralization and leaf litter preference by the earthworm Pontoscolex corethrurus on iron ore mine wastes. Restor. Ecol. 4:475-482. 
451

452

453

454

455

456

457

458

459

460

461

462

463

464

465

466

467

468

469

470

471

472

García-Pérez JA, Alarcón-Gutiérrez E, Perroni Y, Barois I. 2014. Earthworm communities and soil properties in shaded coffe plantations with and without application of glyphosate. Applied Soil Ecology 83:230-237.

García JA, Fragoso C. 2003. Influence of different food substrates on growth and reproduction of two tropical earthworms species (Pontoscolex corethrurus and Amynthas corticis). Pedobiologia 47:754-763.

Gates GE. 1954. Exotic earthworms of the United States. Bulletin of the Museum of Comparative Zoology at Harvard College 111:217-258.

Geissen V, Peña-Peña K, Huerta E. 2009. Effects of different land use on soil chemical properties, decomposition rate and earthworm communities in tropical Mexico. Pedobiologia 53:75-86.

Gerard BM. 1967. Factors affecting earthworms in pastures. Journal of Animal Ecology 36:235-252.

González G, Huang ChY, Zou X, Rodríguez C. 2006. Earthworm invasions in the tropics. Biological Invasions 8:1247-1256.

González G., García E, Cruz V, Borges S, Zalamea M, Rivera MM. 2007. Earthworm communities along an elevation gradient in Northeastern Puerto Rico. Eur. J. Soil Biol. 43:S24-S32.

Gutiérrez-Sarmiento MC, Cardona CM. 2014. Caracterización ecológica de las lombrices de tierra (Pontoscolex corethrurus) como indicadoras de suelos compactados en condiciones de alta humedad del suelo con diferentes coberturas vegetales (Zipacón, Cundinamarca). Revista Cientifica 19:41-55. 
473

474

475

476

477

478

479

480

481

482

483

484

485

486

487

488

489

490

491

492

493

494

495

Hallaire V, Curmi P, Duboisset A, Lavelle P, Pashanasi B. 2000. Soil structure changes induced by the tropical earthworm Pontoscolex corethrurus and organic inputs in a Peruvian ultisol. Eur. J. Soil Biol. 36:35-44.

Hendrix PF, Callaham Jr. MA, Drake JM, Huang ChY, James SW, Snyder BA, Zhang W. 2008. Pandora's box contained bait: the global problem of introduced earthworm. Ann. Rev. Ecol. Evol. S. 39:593-613.

Hernández-Castellanos B, Barois I, Brown GG, García-Pérez A. 2010. Modificaciones químicas inducidas por dos especies de lombrices geófagas en suelos de Veracruz, México. Acta Zoológica Mexicana (n.s.) 2:295-308.

Huerta E, Rodríguez-Olán J, Evia-Castillo I, Montejo-Meneses E, Cruz-Mondragón M, García-Hernández R, Uribe S. 2007. Earthworm and soil properties in Tabasco, Mexico. European Journal of Soil Science 43:S190-S195.

Huerta E, van der Wal H. 2012. Soil macroinvertebrates' abundance and diversity in home gardens in Tabasco, Mexico, vary with soil texture, organic matter and vegetation cover. European Journal of Soil Science 50:68-75.

ISO, International Organization for Standarization. 2011. Soil quality - Sampling of soil invertebrates - Part 5: Sampling and extraction of soil macro-invertebrates. ISO 11268 5. Geneva, Switzerland.

Janion-Scheepers C, Measey J, Braschler B, Chown SL, Coetzee L, Colville JF, Dames J, Davies AB, Davies SJ, Davis ALV, Dippenaar-Schoeman AS, Duffy GA, Fourie D, Griffiths C, Haddad CR, Hamer M, Herbert DG, Hugo-Coetzee EA, Jacobs A, Jacobs K, van Rensburg CJ, Lamani S, Lotz LN, Louw SM, Lyle R, Malan AP, Marais M, Neethling JA, Nxele TC, Plisko DJ, Prendini L, Rink AN, Swart A, 

Wilson JRU. 2016. Soil biota in megadiverse country: current knowledge and future research direction in South Africa. Pedobiologia 59:129-174.

Jiménez JJ, Decaëns T, Lavelle P, Rossi JP. 2012. Soil environmental heterogeneity allows spatial co-occurrence of competitor earthworm species in a gallery forest of the Colombian 'Llanos'. Oikos 121:915-926.

503

Jones AR, Orton TG, Dalal RC. 2016. The legancy of cropping history reduces the recovery of soil carbon and nitrogen after conversion from continuous cropping to permanent pasture. Agriculture, Ecosystems and Environment 216: 166-176.

Jones CG, Lawton JH, Shachak M. 1994. Organisms as ecosystem engineers. Oikos 69:373-386.

King RA, Tibble ML, Symondson OC. 2008. Opening a can of worms: unprecedented sympatric cryptic diversity within British lumbricid earthworms. Molecular Ecology 17:4684-4698.

Kok HY, Azwady AA, Loh KE, Muskhazli M, Zulkifli SZ. 2014. Optimal stoking density for culturing tropical soil-dwelling earthworm, Pontoscolex corethrurus. Sains Malaysian 43:169-173.

Kottek M, Grieser JC, Beck C, Rudolf B, Rubel F. 2006. World Map of Koppen-Geiger Climate Classification update. Meteorol. Z. 15:259-263.

\section{Krasilnikov P, Gutiérrez-Castorena MC, Ahrens RJ, Cruz-Gaistardo CO, Sergey S,} Solleiro-Rebolledo E. 2013. The soils of Mexico. world soil series. Springer. New York, NY, USA. 
518

519

520

521

522

523

524

525

526

527

528

529

530

531

532

533

534

535

536

537

538

539

\section{Lafont A. Risede JM, Loranger-Merciris G, Clermont-Dauphin C, Dorel M, Rhino B,} Lavelle P. 2007. Effects of the earthworm Pontoscolex corethrurus on banana plants infected or not with the plant-parasitic nematode Rodopholus similis. Pedobiologia, 51:311-318.

Lal R. 2004. Soil carbon sequestration impacts on global climate and food security. Science 304:1623-1627.

Lavelle P, Maury ME, Serrano V. 1981. Estudio Cuantitativo de la fauna del suelo en la región de Laguna Verde, Veracruz: época de lluvias. In: Reyes-Castillo P. (ed.) Estudios Biológicos en el Trópico Mexicano. Institute of Ecology Publications 6:65-100.

Lavelle P, Barois I, Cruz I, Fragoso C, Hernández A, Pineda, A, Rangel P. 1987. Adaptive strategies of Pontoscolex corethrurus (Glossscolecidae, Oligochaeta), a peregrine geophagous earthworm of the humid tropics. Biol. Fertil. Soils 5:188-194.

Marichal R, Feijoo MA, Praxedes C, Ruiz D, Carvajal AF, Oszwald J, Hurtado MP, Brown GG, Grimaldi M, Desjardins T, Sarrazin M, Deaëns T, Velasquez E, Lavelle P. 2010. Invasion of Pontoscolex corethrurus (Glossoscolecidae, Oligochaeta) in landscapes of the Amazonian deforestation arc. Appl. Soil Ecol. 46:443-449.

Marichal R, Grimaldi M, Mathieu J, Brown GG, Desjardins T, Lopes da Silva Jr. M, Praxedes C, Martins MB, Velasquez E. 2012. Is invasion of deforested Amazonia by earthworm Pontoscolex corethrurus driven by soil texture and chemical properties?. Pedobiologia S5:233-240.

Mislevy P, Martin FG. 2006. Biomass yield and forage nutritive value of Cynodon grasses harvested monthly. Soil Crop Sci Soc Florida Proc 65:9-14. 
540

541

542

543

544

545

546

547

548

549

550

551

552

553

554

555

556

557

558

559

560

561

Müller F. 1857. Description of a new species of earthworm (Lumbricus corethrurus). The Annals and Magazine of Natural History 20:13-15.

Nath S, Chaudhuri PS. 2014. Growth and reproduction of Pontoscolex corethrurus (Müller) with different experimental diets. Tropical Ecology 55:305-312.

Ordaz CM, Barois I, Aguilar AS. 1996. Fauna del suelo de la sabana de Huimanguillo alterada por cambios en el uso de la tierra. Terra 14:387-393.

Orgiazzi A, Bardgett RD, Barrios E, Behan-Pelletier V, Briones MJI, Chotte J-L, De Deyn GB, Eggleton P, Fierer N, Fraser T, Hedlund K, Jeffery S, Johnson NC, Kandler E, Kaneko N, Lavelle P, Lemanceau P, Miko L, Montanarella L, Moreira FMS, Ramirez KS, Scheu S, Singh BK, Six J, van der Putten WH, Wall DH. 2016. Global Soil Biodiversity Atlas. European Commission publications Office of the European Union. Luxembourg.

Patrón JC, Sánchez P, Brown GG, Brossard M, Barois I, Gutiérrez C. 1999. Phosphorus in soil and Bracharia decumbens plants as affected by the geophagous earthworm Pontoscolex corethrurus and P fertilization. Pedobiologia 43:547-556.

Peel MC, Finlayson BL, McMahon TA. 2007. Updated world map of the Köppen-Geiger climate classification. Hydrol. Earth Syst. Sci. 11:1633-1644.

Plisko JD. 2001. Notes on the occurrence of the introduced eathworm Pontoscolex corethrurus (Müller, 1857) in South Africa (Oligocheta: Glossoscolecidae). African Invertebrates 42, 323-334.

R Core Team 2015. $R$ : a language and environment for statistical computing. Vienna: $\mathrm{R}$ Foundation for Statistical Computing. Available at http://www.R-project.org/. 
562

563

564

565

566

567

568

569

570

571

572

573

574

575

576

577

578

579

580

581

582

583

584

Rutgers M, Orgiazzi A, Gardi C, Römbke J, Jänsch S, Keith AM, Neilson R, Boag B, Schmidt O, Murchie K, Blackshaw RP, Pérès G, Cluzeau D, Guernion M, Briones MJI, Rodeiro J, Piñeiro R, Díaz-Cosín DJ, Souza JP, Suhadolc M, Kos I, Krogh PH, Faber JH, Mulder C, Bogte JJ, van Wijnen HJ, Schouten AJ, de Zwart D. 2016. Mapping earthworm communities in Europe. Applied Soil Ecology 97: 98-111.

\section{SEMARNAT. Official Mexican Norm NOM-021-SEMARNAT 2000.2002.} Specifications of fertility, Salinity, Soil classification, survey, sampling and analysis. Official Journal of the Federation. DF, Mexico, www.economia-noms.gob.mx/.

Stanton NL. 1988. The underground in grassland. Annual Review of Ecology and Systematics 19:573-589.

Stockdill SMJ. 1966. The effects of earthworms on pastures. Proc NZ Ecol Soc 13:68-75.

Topoliantz S, Ponge JF. 2005. Charcoal consumption and casting activity by Pontoscolex corethrurus (Glossoscolecidae). Appl. Soil Ecol. 28:217-224.

Trevaskis LM, Fulkerson WJ, Nandra KS. 2004. Rice increases productivity comparaed to other carbohydrate supplements in dairy coes grazing kikuyu (Pennisetum clandestinum), but not ryegrass (Lolium multiflorum), pastures. Livestock Production Science 87:197-206.

Trujillo W, Fisher MJ, Lal R. 2005. Root dynamics of native savanna and introduced pastures in the Eastern Plains of Colombia. Soil \& Tillage Research 87:28-38.

Turbé A De Toni, Benito P, Lavelle P, Lavelle P, Ruiz N, Van der Putten WH, Labouze E, Mudgal S. 2010. Soil biodiversity: functions, threats and tools for policy makes. Bio Intelligence Service, IRD, and NIOO, Report for European Commission (DG Environment). 
585

586

587

588

589

590

591

592

593

594

595

596

597

598

599

600

601

602

603

604

605

606

607

Uribe S, Huerta E, Geissen V, Mendoza M, Godoy R, Jarquin A. 2012. Pontoscolex corethrurus (Annelida: Oligocheta) indicador de la calidad del suelo en sitios de Eucalyptus grandis (Myrtacea) con manejo tumba y quema. Revista de Biología Tropical 60:1543-552.

Van Groenigen JW, Lubbers IM, Vos HMJ, Brown GG, De Deyn GB, van Groenigen KJ. 2014. Earthworms increase plant production: a meta-analysis. Scientific Reports 4:6365.

Villenave C, Rabary B, Kichenin E, Djigal D, Blanchart E. 2010. Earthworms and plant residues modify nematodes in tropical cropping soils (Madagascar): a mesocosm experiment. Applied and Environmental Soil Science 323-640.

Wright AL, Hons FM, Rouquette FMJr. 2004. Long-term management impacts on soil carbon and nitrogen dynamics of grazed bermudagrass pastures. Soil Biol Biochem 36:1809-1816.

Zavala-Cruz J, Trujillo-Capistrán F, Ortiz-Ceballos G, Ortiz-Ceballos AI. 2013. Tropical endogeic earthworm population in a pollution gradient with weathered crude oil. Res. J. Environ. Sci. 7:15-26.

Zhang H, Yang XD, Du J, Wu YX. 2008. Influence of soil temperature and moisture on the cocoon production and hatching of the exotic earthworm Pontoscolex corethrurus. Zoological Research 29:305-312.

Zou X, González G. 1997. Changes in earthworm density and community structure during secondary succession in abandoned tropical pastures. Soil Biol. Biochem. 29:627-629.

Zou X. 1993. Species effects on earthworm density in tropical tree plantations in Hawaii. Biol. Fertil. Soils 15:35-38. 
Figure $\mathbf{1}$ (on next page)

Sampling sites of earthworms along an altitudinal gradient in central Veracruz, Mexico. For each site, the geographical coordinates (14N zone, Datum WGS84) are presented.

LV = Laguna Verde (11-55 masl), LC = La Concepción (992-1025 masl), NA = Naolinco (1550-1619 masl), AC = Acatlán (1772-1800 masl). Digital elevation model created using the geographical data provided by Instituto Nacional de Estadística y Geografía, Mexico. 


\section{Figure 2 (on next page)}

Abundance (a) and proportion (b) of Pontoscolex corethrurus and total earthworm community abundance (c) along an altitudinal gradient.

LV = Laguna Verde (11-55 masl), LC = La Concepción (992-1025 masl), NA = Naolinco (1550-1619 masl), AC = Acatlán (1772-1800 masl). 

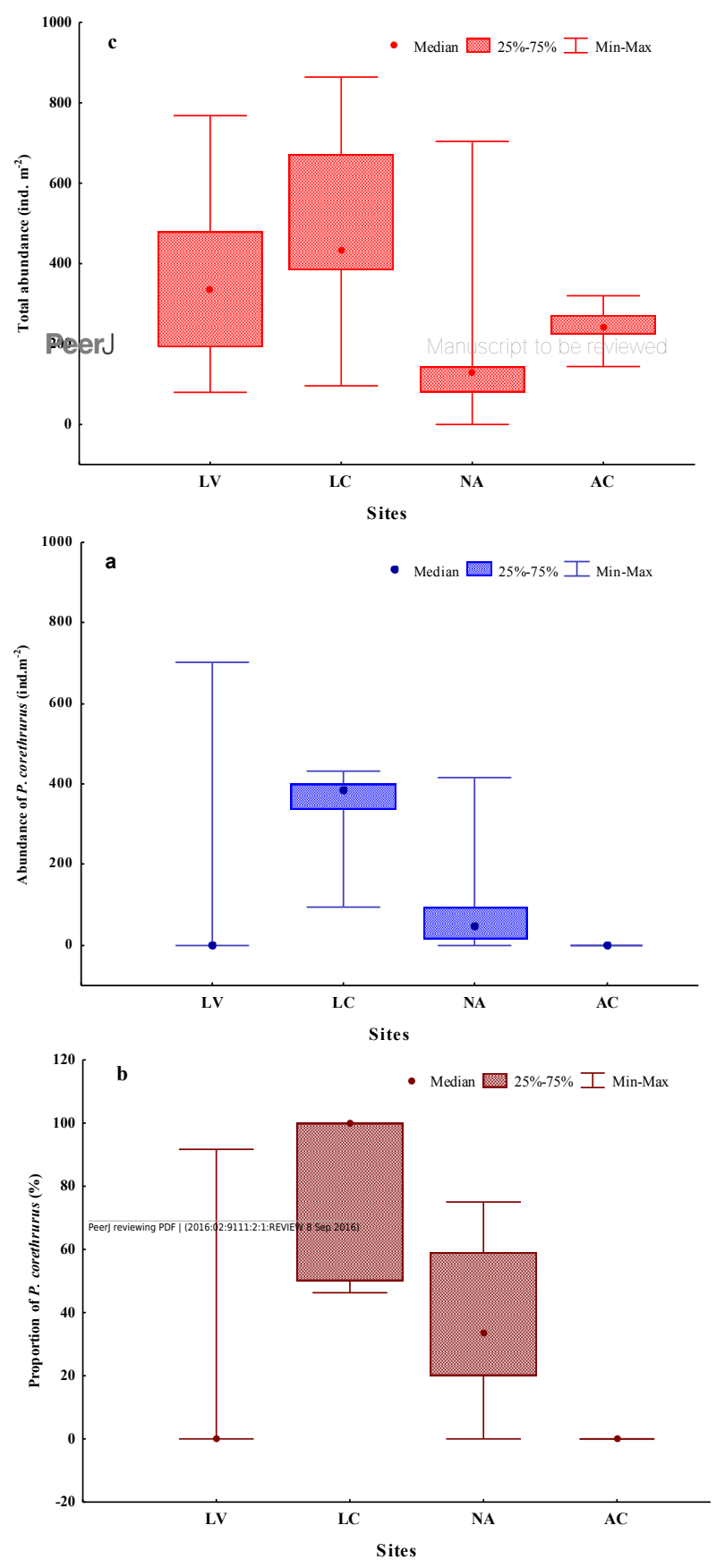


\section{Table $\mathbf{1}$ (on next page)}

Climate variables at the four sampling sites along an altitudinal gradient in central Veracruz, Mexico.

LV = Laguna Verde (11-55 masl), LC = La Concepción (992-1025 masl), NA = Naolinco (1550-1619 masl), AC = Acatlán (1772-1800 masl). AT = Average temperature, AMT =

Average maximum temperature, $\mathrm{AmT}=$ Average minimum temperature, $\mathrm{TAP}=$ total annual precipitation, $\mathrm{TE}=$ total evapotranspiration . 
1

2

3

4

5

6

7

8

9

10

\begin{tabular}{lcccccccc}
\hline Site & Altitude & \multicolumn{3}{c}{ Temperature $\left({ }^{\circ} \mathrm{C}\right)$} & TAP & TE & Month most \\
\cline { 2 - 8 } & (masl) & AT & AMT & AmT & $(\mathrm{mm})$ & Warmer & Cooler \\
& & & & & & & & \\
\hline LV & $11-55$ & $26.0 \pm 2.5$ & $30.0 \pm 2.5$ & $21.0 \pm 2.0$ & 1143.0 & 1618.1 & June & January \\
LC & $992-1025$ & $20.0 \pm 2.0$ & $26.0 \pm 2.2$ & $14.0 \pm 1.8$ & 1676.8 & 1322.0 & May & January \\
NA & $1550-1619$ & $17.0 \pm 2.0$ & $22.2 \pm 2.0$ & $12.0 \pm 1.9$ & 1462.0 & 1554.8 & May & January \\
AC & $1772-1800$ & $15.0 \pm 1.8$ & $20.0 \pm 1.9$ & $10.0 \pm 1.8$ & 1461.0 & 1190.8 & May & January
\end{tabular}

11 
Table 2 (on next page)

Soil properties and grass at the four sites along an elevation gradient in central Veracruz, Mexico.

LV = Laguna Verde (11-55 masI), LC = La Concepción (992-1025 masI), NA = Naolinco (1550-1619 masl), AC = Acatlán (1772-1800 masl). 
3

\begin{tabular}{|c|c|c|c|c|}
\hline Parameter & LV & $\mathrm{LC}$ & NA & $\mathrm{AC}$ \\
\hline Clay, $\%$ & $27.6 \mathrm{~b}$ & $25.6 \mathrm{~b}$ & $12.0 \mathrm{a}$ & $13.6 \mathrm{a}$ \\
\hline Silt, \% & $21.8 \mathrm{a}$ & $34.4 \mathrm{~b}$ & $28.8 \mathrm{ab}$ & $35.8 \mathrm{~b}$ \\
\hline Sand, $\%$ & $50.6 \mathrm{ab}$ & $40.0 \mathrm{a}$ & $59.2 \mathrm{~b}$ & $50.6 \mathrm{ab}$ \\
\hline $\mathrm{pH},\left(\mathrm{H}_{2} \mathrm{O}\right)$ & $6.6 \mathrm{~b}$ & $6.6 \mathrm{~b}$ & $5.5 \mathrm{a}$ & $5.6 \mathrm{a}$ \\
\hline Water-holding capacity, \% & $32.9 \mathrm{a}$ & $36.6 \mathrm{a}$ & $83.5 \mathrm{~b}$ & $70.5 \mathrm{~b}$ \\
\hline Permanent wilting point, $\%$ & $20.0 \mathrm{a}$ & $20.2 \mathrm{a}$ & $53.0 \mathrm{~b}$ & $40.4 \mathrm{~b}$ \\
\hline Organic matter, $\%$ & $8.0 \mathrm{a}$ & $8.4 \mathrm{a}$ & $43.7 \mathrm{~b}$ & $34.2 \mathrm{~b}$ \\
\hline Total N, \% & $0.31 \mathrm{a}$ & $0.31 \mathrm{a}$ & $1.13 \mathrm{c}$ & $0.83 \mathrm{~b}$ \\
\hline $\mathrm{C} / \mathrm{N}$ & $15 \mathrm{a}$ & $16 \mathrm{a}$ & $22 \mathrm{~b}$ & $24 \mathrm{~b}$ \\
\hline $\mathrm{P}, \mathrm{mg} \mathrm{kg}^{-1}$ & $13.2 \mathrm{a}$ & $54.7 \mathrm{c}$ & $49.8 \mathrm{~b}$ & $14.2 \mathrm{a}$ \\
\hline $\mathrm{K}, \mathrm{cmol}_{\mathrm{c}} \mathrm{kg}^{-1}$ & $1.1 \mathrm{a}$ & $1.7 \mathrm{a}$ & $2.8 \mathrm{~b}$ & $1.4 \mathrm{a}$ \\
\hline Ngrass, $\%$ & $1.1 \mathrm{a}$ & $0.71 \mathrm{a}$ & $1.46 \mathrm{~b}$ & $1.45 \mathrm{~b}$ \\
\hline
\end{tabular}




\section{Table 3(on next page)}

Earthworm species recorded in four sampling sites along an altitudinal gradient in central Veracruz, Mexico.

LV = Laguna Verde (11-55 masl), LC = La Concepción (992-1025 masl), NA = Naolinco (1550-1619 masl), AC = Acatlán (1772-1800 masl). 
1

2

3

4

5

6

7

8

9

10

11

\begin{tabular}{|c|c|c|c|c|c|c|c|c|}
\hline \multirow[t]{2}{*}{ Species } & \multirow[t]{2}{*}{ Family } & \multirow[t]{2}{*}{ Origin } & \multirow[t]{2}{*}{ Parthenogenetic } & \multirow[t]{2}{*}{$\begin{array}{l}\text { Ecological } \\
\text { category }\end{array}$} & \multicolumn{4}{|c|}{$\begin{array}{c}\text { Sites and average density } \\
\left.\text { (ind. } / \mathbf{m}^{2}\right)\end{array}$} \\
\hline & & & & & $\mathbf{L V}$ & LC & NA & $\mathrm{AC}$ \\
\hline Pontoscolex corethrurus & Rhinodrilidae & South America & + & Endogeic & 141 & 330 & 144 & 0 \\
\hline Onychochaeta windlei & Rhinodrilidae & South America & + & Endogeic & 0 & 320 & 0 & 0 \\
\hline Morfo 1 & Morfospecies & Mexico & Uncertain & Endogeic & 264 & 0 & 0 & 0 \\
\hline Morfo 2 & Morfospecies & Mexico & Uncertain & Endogeic & 155 & 0 & 0 & 0 \\
\hline Morfo 3 & Morfospecies & Mexico & Uncertain & Endogeic & 160 & 0 & 0 & 0 \\
\hline Amynthas gracilis & Megascolecidae & Asia & + & $\begin{array}{l}\text { Epi- } \\
\text { endogeic }\end{array}$ & 0 & 240 & 53 & 80 \\
\hline Octolasion tyrtaeum & Lumbricidae & Europe & - & Endogeic & 0 & 0 & 120 & 67 \\
\hline Aporrectodea trapezoides & Lumbricidae & Europe & + & Endogeic & 0 & 0 & 0 & 128 \\
\hline Lumbricus rubellus & Lumbricidae & Europe & - & $\begin{array}{l}\text { Epi- } \\
\text { endogeic }\end{array}$ & 0 & 0 & 0 & 72 \\
\hline Bimastos parvus & Lumbricidae & North America & + & Epigeic & 0 & 0 & 0 & 21 \\
\hline
\end{tabular}

12 


\section{Table 4 (on next page)}

Estimated regression coefficients in the linear model that predict total earthworm abundance along an altitudinal gradient in central Veracruz, Mexico.

Sites: LV = Laguna Verde (11-55 masI), LC = La Concepción (992-1025 masl), NA = Naolinco (1550-1619 masl), AC = Acatlán (1772-1800 masl). *The "site" was included in the linear model using Dummy variables with the reference cell method. The reference site was LV. We performed an analysis of variance for this linear model; the P-value associated to the site effect was 0.0652 . 
1

2

3

\begin{tabular}{|c|c|c|c|c|}
\hline Factors & $\begin{array}{c}\text { Estimate } \\
\text { Coefficients }\end{array}$ & Std. Error & $\mathbf{t}$ & $\boldsymbol{P}$ \\
\hline Intercept & 44.410 & 1882.0 & 0.024 & 0.982 \\
\hline Site $\mathrm{AC}^{*}$ & -0.394 & 0.792 & -0.497 & 0.645 \\
\hline Site LC* & 0.626 & 0.554 & 1.130 & 0.322 \\
\hline Site NA* & -0.324 & 1.095 & -0.296 & 0.782 \\
\hline Clay, $\%$ & -0.133 & 0.067 & -1.98 & 0.118 \\
\hline Sand, \% & 0.001 & 0.034 & 0.06 & 0.957 \\
\hline Water-holding capacity, $\%$ & -0.208 & 0.061 & -3.43 & 0.026 \\
\hline Permanent wilting point, $\%$ & 0.484 & 0.128 & 3.77 & 0.019 \\
\hline $\mathrm{pH},\left(\mathrm{H}_{2} \mathrm{O}\right)$ & 0.920 & 0.322 & 2.86 & 0.045 \\
\hline Organic matter, $\%$ & 0.156 & 0.044 & 3.32 & 0.029 \\
\hline Total N, \% & -18.090 & 4.420 & -4.01 & 0.015 \\
\hline $\mathrm{P}, \mathrm{mg} \mathrm{kg} \mathrm{kg}^{-1}$ & 0.018 & 0.006 & 3.26 & 0.031 \\
\hline $\mathrm{K}, \mathrm{cmol}_{\mathrm{c}} \mathrm{kg}^{-1}$ & -1.053 & 0.263 & -4.01 & 0.016 \\
\hline Ngrass, $\%$ & 3.559 & 0.770 & 4.62 & 0.009 \\
\hline
\end{tabular}

4 


\section{Table 5 (on next page)}

Earthworm community composition in each of the five monoliths at the four sites along an altitudinal gradient in central Veracruz, Mexico:

no earthworms, Pontoscolex corethrurus only, coexistence (exotic and native), others species (but no $P$. corethrurus). LV = Laguna Verde (11-55 masI), LC = La Concepción (992-1025 masl), NA = Naolinco (1550-1619 masl), AC = Acatlán (1772-1800 masl). 
2

3

4

5

6

7

8

9

\begin{tabular}{lccccccc}
\hline \multirow{2}{*}{ Sites } & No Earthworm & \multicolumn{2}{c}{$\boldsymbol{P}$ corethrurus only } & \multicolumn{2}{c}{ Coexistence } & Others species only & \multirow{2}{*}{ Total } \\
\cline { 3 - 6 } & & & Exotic & Native & Exotic & Native & \\
\hline LV & 0 & 0 & 0 & 1 & 0 & 4 & 5 \\
LC & 0 & 3 & 2 & 0 & 0 & 0 & 5 \\
NA & 1 & 0 & 4 & 0 & 0 & 0 & 5 \\
AC & 0 & 0 & 0 & 0 & 5 & 0 & 5 \\
\hline Total & 1 & 3 & 6 & 1 & 5 & 4 & 20 \\
\hline
\end{tabular}

10 